\title{
Fe(III)-DOXYCYCLINE COMPLEXES WITH DIIMINE LIGANDS: SYNTHESES, CHARACTERIZATION AND BIOLOGICAL PROPERTIES
}

\author{
Joshua A. Obaleye ${ }^{1, *}$ and Olufunso O. Abosede ${ }^{1,2}$ \\ ${ }^{1}$ Department of Chemistry, University of Ilorin, P.M.B. 1515, Ilorin, Nigeria \\ ${ }^{2}$ Department of Chemistry, Federal University Otuoke, P.M.B. 126, Yenagoa, Bayelsa State \\ jobaleye@yahoo.com; jobaleye@ unilorin.edu.ng
}

\begin{abstract}
Three new iron(III) complexes of doxycycline viz: $\left[\mathrm{Fe}(\mathrm{dox})_{2} \mathrm{Cl}_{3} \mathrm{Cl}_{2}(\mathbf{1})\right.$, $[\mathrm{Febpy}(\mathrm{dox}) \mathrm{Cl}] \mathrm{Cl}_{2}(\mathbf{2})$ and $[\mathrm{Fephen}(\operatorname{dox}) \mathrm{Cl}] \mathrm{Cl}_{2}$ (3), where dox is doxycycline, bpy is $2,2^{\prime}$-bipyridine and phen is 1,10 phenanthroline, were synthesized and characterized by elemental analysis, electronic absorption, FT-IR, and electrospray ionization mass spectroscopy. Doxycycline and the polypyridyl ligands behave as bidendate ligands; the polypyridyl ligands coordinate through the two diimine nitrogen atoms and doxycycline through enolate and diketoamide oxygen atoms of ring $\mathrm{A}$ in a five-coordinate system with chloride atom in the axial position. Their antibacterial and antiplasmodial activities against chloroquinesensitive Plasmodium falciparum NF54 and their interaction with calf thymus (CT) DNA using electronic titration were investigated. The three complexes showed good activity against strains of Staphylococcus aureus and Klebsiella pneumonia. The complexes bind moderately to CT DNA with binding constants of $5.6 \times 10^{4}$ and $4.8 \times 10^{4}$ for complexes $\mathbf{2}$ and $\mathbf{3}$, respectively.
\end{abstract}

Keywords: doxycycline; iron(III); diimine; antibacterial; DNA binding; antiplasmodial

\section{Fе(III)-ДОКСИЦИКЛИНСКИ КОМПЛЕКСИ СО ДИИМИНСКИ ЛИГАНДИ: СИНТЕЗИ, КАРАКТЕРИЗАЦИЈА И БИОЛОШКИ СВОЈСТВА}

\begin{abstract}
Синтетизирани се три нови комплекси на железо(III) со доксициклин, имено: $\left[\mathrm{Fe}(\operatorname{dox})_{2} \mathrm{Cl}\right] \mathrm{Cl}_{2}(\mathbf{1}),[\mathrm{Febpy}(\operatorname{dox}) \mathrm{Cl}] \mathrm{Cl}_{2}$ (2) и $[\mathrm{Fephen}(\operatorname{dox}) \mathrm{Cl}] \mathrm{Cl}_{2}(\mathbf{3})$, каде dox е доксициклин, bpy e $2,2^{\prime}$-бипиридин и phen e 1,10-фенантролин, кои се карактеризирани со елементна анализа, електронска апсорпција, FT-IR и масена спектроскопија со електронспреј јонизација. Доксициклинот и лигандите на полипиридил се однесуваат како бидентатни лиганди; лигандите полипиридил се координираат преку двата диимински азотни атоми, додека доксициклинот преку енолатните и дикетоамидните кислородни атоми на прстенот А во петочлен координатен систем со хлорниот атом во аксијална положба. Со електронска титрација беше испитано и нивното антибактереиско и антиплазмоидно дејство врз хлорохинон осетливите Plasmodium falciparum NF54, како и нивната интеракција со DNA од телешки тимус (CT). Трите комплекси покажаа добро дејство врз Staphylococcus aureus и Klebsiella pneumonia. Комплексите умерено се сврзуваат со CT DNA со константи на сврзување, соодветно, од 5,6 $\times 10^{4}$ and 4,8 $\times 10^{4}$ за комплексите 2 и 3.
\end{abstract}

Клучни зборови: доксициклин; железо(III); диимин; антибактериски; DNA сврзување; антиплазмоиден

\section{INTRODUCTION}

Among the tetracyclines, doxycycline is an antibiotic with pleiotropic properties [1-3].
Doxycycline alone or in combination with another compound has been widely used for treatment of diverse antibacterial infections. Besides the use of doxycycline as broad spectrum antibiotic, new uses 
have emerged including its use as slow-acting but effective anti-malarial agent [4-5], its potential in matrix metalloproteinase (MMP) inhibition [6] and in anticancer therapy [7-10].

The binding of tetracyclines and chemically modified tetracyclines (CMTs) to metal ions has been implicated in their biological activities [1113]. DNA strand breakage by tetracycline alone and the role of metal ions in tetracycline-induced strand cleavage have been demonstrated [14]. DNA binding, cleavage and cytotoxicity of two new ternary copper(II) complexes of 1,10phenanthroline with doxycycline and tetracycline have also been reported [15-16]. Bipyridine (bpy) (Scheme 1) and other polypyridyl derivatives, both as ligands and as transition metal complexes, play active roles in the normal functioning of a number of biological systems [17]. Such bioactivities of the free polypyridyl ligands are usually associated with the sequestering of trace metals at the active site and the active species are always the resulting metal complexes.<smiles></smiles>

Scheme I. Ligands used

The inertness and structural versatility of polypridyl ligand complexes have been used to probe their interactions with DNA and the formation of non-covalent adducts with essential proteins in cells [15-16]. Chemical properties such as hydrophobicity and redox potentials of polypyridyl ligands have also been exploited to obtain complexes with cytotoxic and enzyme-inhibition properties [19]. The diimine chelating ligands such as 2,2'-bipyridine (bpy) and 1,10-phenanthroline (phen) generally bind moderately strongly to $\mathrm{Fe}(\mathrm{III})$ giving stable complexes and their homoleptic and mixed diimine ligand complexes have been reported for various applications, including DNA interactions [20-22]. Tetracyclines are also avid iron chelators and form moderately stable complexes with $\mathrm{Fe}^{3+}$ by acting as an $\mathrm{O}, \mathrm{O}$-donor ligand [23]. The ability of tetracyclines to remove iron from human holotransferrin has been demonstrated [24]. The complexing of iron to bleomycin [16] has been implicated in bleomycin-DNA interactions and the interaction of some $\mathrm{Fe}^{\mathrm{III}}$-diimine complexes with DNA has also been reported [2526]. Iron, often as complexes, plays many vital roles in biology and medicine [27-29].

These significant bioactivities of iron(III) and tetracycline complexes prompted us to synthesize three iron(III) complexes of doxycycline namely
$\left[\mathrm{Fe}(\operatorname{Dox})_{2} \mathrm{Cl} \mathrm{Cl}_{2}\right.$ (1), $[\mathrm{Febpy}($ Dox $) \mathrm{Cl}] \mathrm{Cl}_{2}$ (2) and $[\mathrm{Fephen}(\mathrm{Dox}) \mathrm{Cl}] \mathrm{Cl}_{2}(\mathbf{3})$, where dox is doxycycline, bpy is 2,2'-bipyridine and phen is 1,10phenanthroline. Herein, we report spectroscopic analyses of the complexes, their antibacterial potentials against Staphylococcus aureus and Klebsiella pneumonia strains, their antiplasmodial activity and their interaction with calf thymus DNA (CT DNA) as evidenced by electronic titration of complexes 2 and 3. This work is part of our effort targeted towards synthesizing metal complexes of biologically relevant ligands for various antibacterial and antimalarial applications, [30-33].

\section{EXPERIMENTAL}

\subsection{Materials and methods}

All reagents and solvents were of analytical grade and used without further purification. Doxycycline hyclate was sourced from Neimeth International Pharmaceuticals Plc, Lagos, Nigeria and solutions were freshly prepared to ensure stability; 1,10-phenanthroline monohydrate and iron(III) chloride were obtained from S. D. Fine Chemicals Ltd., India and used as received. Chloroquine diphosphate was obtained from Sigma. 
UV/Vis spectra were recorded on a Jasco UV-vis spectrophotometer. Infrared spectra were recorded in the range of 4,000-400 $\mathrm{cm}^{-1}$ on samples pressed into $\mathrm{KBr}$ pellets. Elemental analyses were taken on Elementar Analysen Systeme Vario ${ }^{\circledR}$ MICRO VI $6.2 \mathrm{GmbH}$. Melting points were taken on Jenway digital melting point apparatus and were uncorrected. Electrospray mass spectra were recorded on a THERMO-Finningan-LCQ Advantage max ion trap mass spectrometer. A $10 \mu 1$ methanol solution of the sample was introduced into the ESI source through Finnigan surveyor autosampler. Methanolwater $(90: 10)$ was used as the mobile phase and flowed at a rate of $250 \mu \mathrm{l} / \mathrm{min}$ by MS pump. The ion spray voltage was set at $5.3 \mathrm{KV}$ and the capillary voltage was $34 \mathrm{~V}$. The MS scan was $2.5 \mathrm{~min}$ and the spectra printouts were averaged of over 10 scans at the peak top in Total Ion Chromatogram (TIC).

\subsection{Synthesis of the complexes}

\subsubsection{Preparation of $\left[\mathrm{FeDox}{ }_{2} \mathrm{Cl} \mathrm{Cl}_{2} \cdot 6 \mathrm{H}_{2} \mathrm{O}(\mathbf{1})\right.$}

$0.041 \mathrm{~g}(0.25 \mathrm{mmol})$ of anhydrous ferric chloride was dissolved in $10 \mathrm{ml}$ of methanol and $0.256 \mathrm{~g}(0.5 \mathrm{mmol})$ of doxycycline hyclate was added. The resulting brown solution was stirred for $4 \mathrm{~h}$, filtered and allowed to evaporate slowly at room temperature precipitating brown powder after a few days. The brown powder was washed with acetone and dried in a vacuum desiccator. Anal. Calc. for $\mathrm{C}_{44} \mathrm{H}_{60} \mathrm{Cl}_{3} \mathrm{~N}_{4} \mathrm{O}_{22} \mathrm{Fe}: \mathrm{C}, 45.59 ; \mathrm{H}, 5.22 ; \mathrm{N}$, 4.83. Found: C, 45.35; H, 5.61; N, 4.80. FT-IR $\left(\mathrm{KBr}, \mathrm{v} / \mathrm{cm}^{-1}\right)$ : 3205, 1610, 1562, 1445, 1323, $1240,1214,1169,1128,1038,1001,935,865$, 824, 803, 706, 659 .

\subsubsection{Preparation of [FebpyDoxCl]Cl $\mathrm{Cl}_{2}$ (2)}

$0.128 \mathrm{~g}(0.25 \mathrm{mmol})$ of doxycycline hyclate was added to $0.041 \mathrm{~g}(0.25 \mathrm{mmol})$ anhydrous ferric chloride in $10 \mathrm{ml}$ methanol and the resulting dark brown solution was stirred for 1 h. $39.5 \mathrm{mg}(0.25$ mmol) of 2,2-bipyridine was added and the solution stirred for additional 2 hours to obtain an orange precipitate. The resulting precipitate was filtered and dried in vacuum desiccator. Anal. Calc. for $\mathrm{C}_{32} \mathrm{H}_{32} \mathrm{Cl}_{3} \mathrm{~N}_{4} \mathrm{O}_{8} \mathrm{Fe}$ : C, 45.06; $\mathrm{H}, 4.96 ; \mathrm{N}, 6.57$. Found: C, 45.06; H, 4.09; N, 6.59. UV-Vis $\left(\mathrm{H}_{2} \mathrm{O}\right.$, $\mathrm{nm}): 231,284,348,368,422$, 518. FT-IR (KBr, $\left.\mathrm{v} / \mathrm{cm}^{-1}\right): 3286,3209,3088,3060,1604,1582$, 1494, 1442, 1241, 1214, 1170, 1127, 1060, 1038, $995,933,882,824,804,763,732,708,674,653$, 617, 582, 546, 507, 442, 417.

\subsubsection{Preparation of [FephenDoxCl]Cl $\mathrm{Cl}_{2} \cdot 5 \mathrm{H}_{2} \mathrm{O}(\mathbf{3})$}

$0.128 \mathrm{~g}(0.25 \mathrm{mmol})$ doxycycline hyclate was added to $0.0401 \mathrm{~g}(0.25 \mathrm{mmol})$ anhydrous ferric chloride in $10 \mathrm{ml}$ aqueous methanol and the resulting dark brown solution stirred for $30 \mathrm{~min} .51$ $\mathrm{mg}(0.25 \mathrm{mmol})$ of 1,10 -phenanthroline was added and the solution was stirred for additional 2 hours to obtain an orange precipitate. The orange precipitate was filtered and dried in vacuum desiccator. Anal. Calc. for $\mathrm{C}_{34} \mathrm{H}_{42} \mathrm{Cl}_{3} \mathrm{~N}_{4} \mathrm{O}_{13} \mathrm{Fe}: \mathrm{C}, 46.57 ; \mathrm{H}$, 4.83; N, 6.39. Found: C, 46.06; H, 4.69; N, 6.59. UV-Vis $\left(\mathrm{H}_{2} \mathrm{O}, \mathrm{nm}\right): 225,267,323,362,401,510$. FT-IR $\left(\mathrm{KBr}, v / \mathrm{cm}^{-1}\right): 3555,3275,2877,1979$, $1587,1518,1446,1429,1384,1325,1244,1219$, $1170,1141,1130,1105,1039,1001,933,873$, $830,823,802,768,725,680,660,615,584,545$, $503,452,447,432$.

\subsection{Antimicrobial susceptibility testing}

Antibacterial susceptibility testing was carried out to compare the antibacterial activities of the complexes with the parent ligand, doxycycline. The in vitro antibacterial activities of all compounds were tested by standard well diffusion method using nutrient agar media. A sterile swab was used to inoculate the organism on the plate. The plate was left for some time so that the inocula would diffuse into the media. A sterile needle was used to make $6 \mathrm{~mm}$ wells uniformly on the surface of the plates. Three wells were made in the seeded plates and were labelled well I, II and III, respectively. Different concentrations of the test solution (5\% aqueous DMSO) were introduced into the wells using a sterile syringe. The plates were then set aside for 1 hour at room temperature to allow proper diffusion of the test solution to occur. All the plates were incubated at $37^{\circ} \mathrm{C}$ for $24-48$ hours before bacteria and zones of inhibition were detected. A zone of clearance round each well indicated inhibition and the diameter of such zones were measured in millimeters $(\mathrm{mm})$.

\subsection{Antiplasmodial study}

Samples of all compounds were tested in triplicate against chloroquine-sensitive (NF54) strains of Plasmodium falciparum. Continuous in vitro cultures of asexual erythrocyte stages of $P$. falciparum were maintained using a modified procedure of Trager and Jensen [35]. Quantitative assessment of in vitro antiplasmodial activity was determined with the parasite lactate dehydrogenase 
assay using a modified method of Makler and Hinrichs [36]. A $20 \mathrm{mg} \mathrm{ml}^{-1}$ stock solution in $100 \%$ DMSO of the test samples were prepared and stored at $-20{ }^{\circ} \mathrm{C}$. Further dilutions were prepared on the day of the experiment. Chloroquine diphosphate (CQDP) was used as the reference drug. A full dose-response experiment was performed for all compounds to determine the concentration inhibiting $50 \%$ of parasite growth ( $\mathrm{IC}_{50}$-value). Samples were tested at a starting concentration of $100 \mu \mathrm{g} \mathrm{ml}^{-1}$, which was then serially diluted twofold in complete medium to give 10 concentrations; with the lowest concentration being $0.2 \mu \mathrm{g}$ $\mathrm{ml}^{-1}$. The reference drug (CQDP) was tested at a starting concentration of $1000 \mathrm{ng} \mathrm{ml}^{-1}$. The highest concentration of the solvent to which the parasites were exposed to had no measurable effect on the parasite viability (data not shown). The $\mathrm{IC}_{50}$-values were obtained using a non-linear dose response curve fitting analysis via Graph Pad Prism v. 4.0 software.

\subsection{DNA binding study by electronic absorption titration}

The electronic absorption spectra of $20 \mu \mathrm{M}$ of the complexes with increasing concentration of nucleotide $(5 \mu \mathrm{M}-150 \mu \mathrm{M})$ were recorded in Tris $\mathrm{HCl}$ buffer following reported procedures [37-38]. Absorption readings were taken after 20 minutes of adding DNA to the metal complexes so as to allow the solutions to equilibrate. Binding constants of complexes were estimated using the equation 1 [39-40].

$$
\frac{[\mathrm{DNA}]}{[\varepsilon a-\varepsilon b]}=\frac{[\mathrm{DNA}]}{[\varepsilon b-\varepsilon f]}+1 / K b[\varepsilon-\varepsilon f]
$$

where [DNA] is the concentration of DNA in base pairs, $\varepsilon_{a}$ is the extinction coefficient observed for the MLCT absorption band at the given DNA concentration, $\varepsilon_{\mathrm{f}}$ is the extinction coefficient of the free (unbound) complex and $\varepsilon_{\mathrm{b}}$ is the extinction coefficient of the fully bound complex. The ratio of the slope $\frac{1}{[\varepsilon a-\varepsilon f]}$ and the intercept $\frac{1}{K b[\varepsilon b-\varepsilon f]}$ obtained from a plot of $[\mathrm{DNA}] /\left[\varepsilon_{\mathrm{a}}-\varepsilon_{\mathrm{f}}\right]$ versus [DNA] gives the intrinsic binding constant [40]. 1 mmol stock solutions of the complexes $\mathbf{1 , 2 , 3}$ were prepared in Tris $\mathrm{HCl}$ buffer.

\section{RESULTS AND DISCUSSION}

\subsection{Synthesis and characterization}

The complexes were obtained in good yield and are stable in solid state and in solution at ambient conditions. UV-Vis, FT-IR and elemental analysis data are in agreement with the proposed structures for the complexes (Scheme 2). The ultraviolet and visible spectra of the complexes are presented in Figure 1. There was no change in the UV-visible spectra of the complexes after dissolution for many hours, demonstrating stability and integrity of these complexes in solution. The FT-IR spectra are given in the supplementary material.

The electrospray ionization mass spectrum of complex 3 was also taken in methanol. The mass spectrum (Fig. 2) shows that the complex has main peaks at 860.1 and 968.8 which corresponds to $[\mathrm{Fe}+\mathrm{dox}+2 \mathrm{phen}]$ and $\left[\mathrm{Fedoxphen}{ }_{2}\right] \mathrm{Cl}_{3}$, respectively.

To establish the coordination sites of doxycycline to $\mathrm{Fe}^{\mathrm{III}}$ we obtained the infrared spectra of doxycycline and the complexes 1, 2 and $\mathbf{3}$. The FTIR spectra of the complexes were then compared to that of doxycycline as assigned in previous published literature $[15,31,33]$.

Amide(I) absorption of doxycycline at 1678 $\mathrm{cm}^{-1}$ appeared at about $1610 \mathrm{~cm}^{-1}$ for complex 1 and $1604 \mathrm{~cm}^{-1}$ for complex 2, while amide(II) absorption band at 1520 of ring A carbonyl stretching $v(\mathrm{C}=\mathrm{O})$ are absent in all the complexes indicating participation of ring A carbonyl oxygen in coordination to $\mathrm{Fe}^{\mathrm{III}}$. Two bands at 1244 and $1219 \mathrm{~cm}^{-1}$ assigned to $\delta\left(\mathrm{NH}_{2}\right)$ and $v\left(\mathrm{C}-\mathrm{NH}_{2}\right)$ of doxycycline are essentially unchanged in the new complexes, indicating that the amino group is not involved in coordination in the complexes.

The bands that appear at $1494 \mathrm{~cm}^{-1}$ in complex 2 and 1518 in complex 3 are due to the phenanthroline and bipyridine $\mathrm{C}=\mathrm{C}$ coordination to iron(III) in complexes $\mathbf{2}$ and $\mathbf{3}$, respectively. Carbonyl stretching $v(\mathrm{C}=\mathrm{O})$ on ring $\mathrm{C}$ at $1616 \mathrm{~cm}^{-1}$ in doxycycline shifted to 1562,1582 and $1587 \mathrm{~cm}^{-1}$ in complexes $\mathbf{1}, \mathbf{2}$ and $\mathbf{3}$, respectively. 

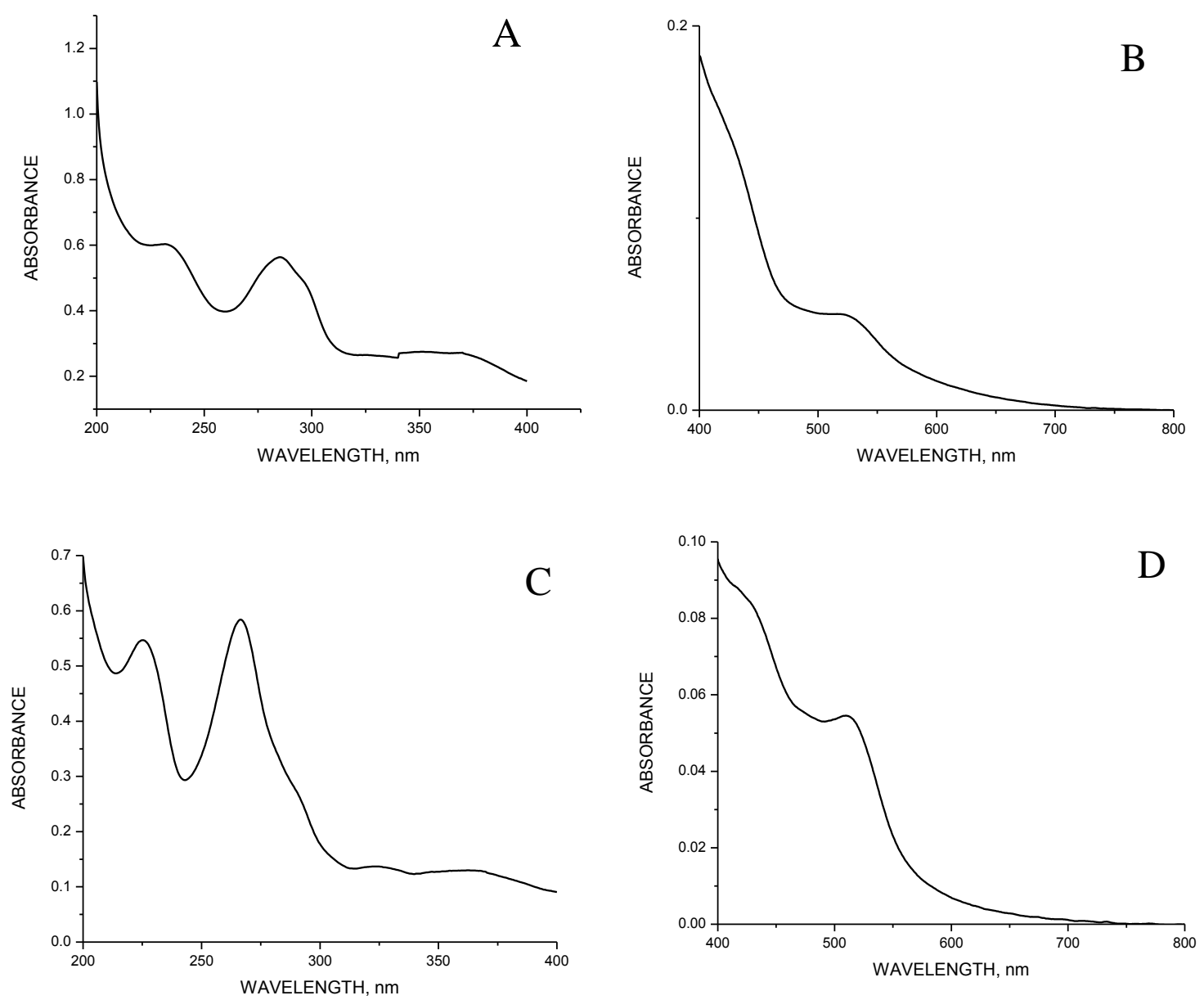

Fig. 1. UV and Bisible spectra of aqueous solutions of complexes $2(A$ and $B)$ and $\mathbf{3}(C$ and D) at $20 \mu \mathrm{M} ; 1=1 \mathrm{~cm}$

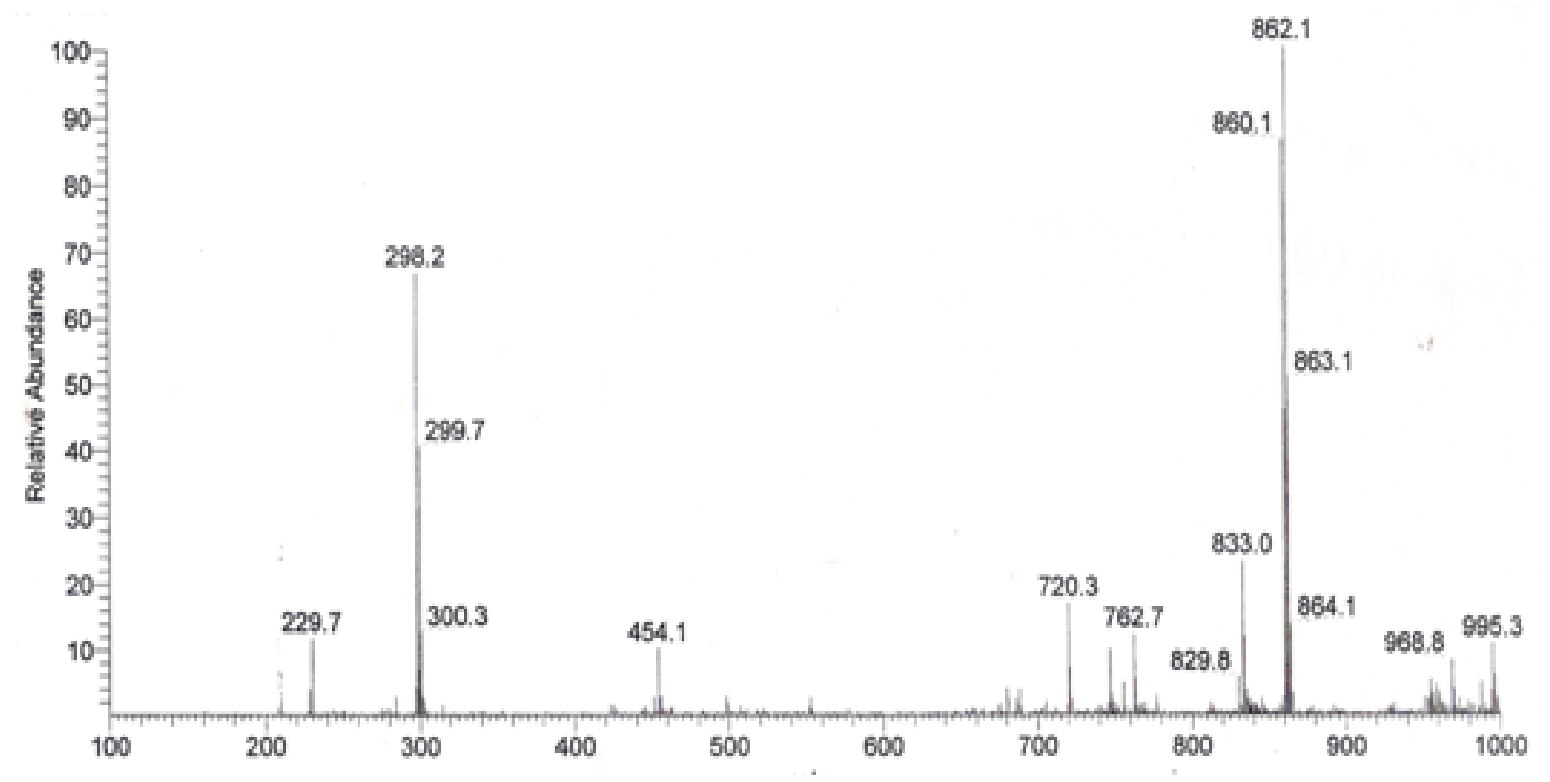

Fig. 2. Electrospray ionization mass spectrum of complex 3 


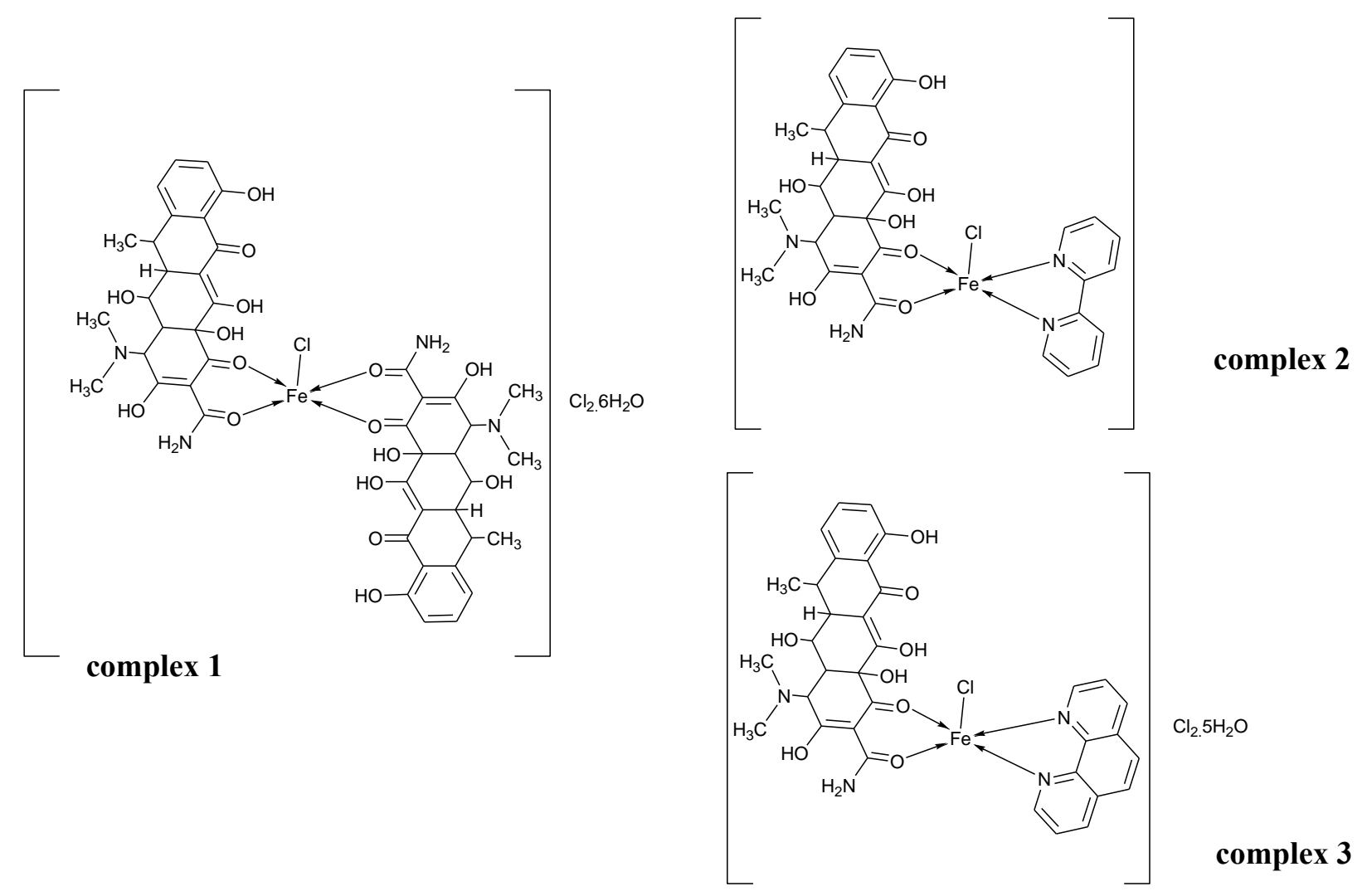

Scheme II. Proposed structures of complexes 1, 2 and $\mathbf{3}$

Table 1

Physicochemical properties of the complexes

\begin{tabular}{cccc}
\hline \hline $\mathbf{S} / \mathbf{N}$ & Complex molecular formula & Melting point $/{ }^{\circ} \mathbf{C}$ & Color \\
\hline $\mathbf{1}$ & {$\left[\mathrm{FeDox}_{2} \mathrm{Cl} \mathrm{Cl}_{2} \cdot 6 \mathrm{H}_{2} \mathrm{O}[1]\right.$} & $203-205$ & Brown \\
$\mathbf{2}$ & {$[\mathrm{FebpyDoxCl}] \mathrm{Cl}_{2}[2]$} & $205-206$ & Brown \\
$\mathbf{3}$ & {$[\mathrm{FephenDoxCl}] \mathrm{Cl}_{2} \cdot 5 \mathrm{H}_{2} \mathrm{O}[3]$} & $196, \mathrm{dec}$ & Orange \\
\hline \hline
\end{tabular}

\subsection{Antimicrobial studies}

\subsubsection{Antibacterial susceptibility testing}

Antimicrobial susceptibilities of the complexes were tested on Staphylococcus aureus and Klebsiella pneumonia as a function of concentration. Staphylococcus aureus and Klebsiella pneumonia are pathogens that cause respiratory and urinary tract infections in humans [41]. Four concentrations of the complexes were taken, i.e. 0.5 $\mathrm{mg} / \mathrm{ml}, 1.0 \mathrm{mg} / \mathrm{ml}, 1.5 \mathrm{mg} / \mathrm{ml}$ and $2.0 \mathrm{mg} / \mathrm{ml}$. The susceptibility of the strains of bacteria towards the complexes were determined by measuring the size of inhibition diameter and compared to that of doxycycline, a standard antibiotic and also the parent ligand. All experiments were performed in triplicate and the standard deviations were negligible. The antibacterial susceptibility tests of the complexes against Staphylococcus aureus and Klebsiella pneumonia are presented in Table 2. The antibacterial activities of the three complexes were in the same range with the parent ligand, doxycycline. The presence of the ancillary polypyridyl ligands did not contribute significantly to the antibacterial activities of the complexes. The coordination of iron alone to doxycycline in the complexes did not improve their antibacterial activity but rather reduced it though to a small extent. 
Table 2

Antibacterial activity of doxycycline and its complexes against

Klebsiella pneumonia and Staphylococcus aureus

\begin{tabular}{|c|c|c|c|c|c|c|c|c|}
\hline \multirow[t]{2}{*}{ AGENTS } & \multicolumn{4}{|c|}{$\begin{array}{l}\text { ZONE OF INHIBITION /mm * } \\
\text { against Klebsiella pneumonia }\end{array}$} & \multicolumn{4}{|c|}{$\begin{array}{c}\text { ZONE OF INHIBITION /mm * } \\
\text { Staphylococcus aureus }\end{array}$} \\
\hline & $0.5 \mathrm{mg}$ & $1.0 \mathrm{mg}$ & $1.5 \mathrm{mg}$ & $2.0 \mathrm{mg}$ & $0.5 \mathrm{mg}$ & $1.0 \mathrm{mg}$ & $1.5 \mathrm{mg}$ & $2.0 \mathrm{mg}$ \\
\hline 1 & $10 \pm 0.2$ & $11 \pm 0.1$ & $13 \pm 0.1$ & $13 \pm 0.2$ & $13 \pm 0.3$ & $14 \pm 0.2$ & $15 \pm 0.1$ & $17 \pm 0.2$ \\
\hline 2 & $12 \pm 0.5$ & $15 \pm 0.7$ & $16 \pm 0.3$ & $16 \pm 0.4$ & $10 \pm 0.6$ & $12 \pm 0.4$ & $13 \pm 0.5$ & $14 \pm 0.3$ \\
\hline 3 & $13 \pm 0.5$ & $14 \pm 0.4$ & $15 \pm 0.5$ & $16 \pm 0.2$ & $12 \pm 0.6$ & $13 \pm 0.4$ & $16 \pm 0.5$ & $17 \pm 0.3$ \\
\hline Doxycycline hyclate & $11 \pm 0.6$ & $12 \pm 0.4$ & $13 \pm 0.5$ & $15 \pm 0.3$ & $15 \pm 0.3$ & $15 \pm 0.5$ & $16 \pm 0.4$ & $17 \pm 0.2$ \\
\hline Cefotaxime $-30 \mu \mathrm{g}[\mathbf{4 2}]$ & \multicolumn{4}{|c|}{31.04} & \multicolumn{4}{|c|}{18.91} \\
\hline Chloramphenicol—-30 $\mu \mathrm{g}[\mathbf{4 2}]$ & \multicolumn{4}{|c|}{24.69} & \multicolumn{4}{|c|}{15.54} \\
\hline $\begin{array}{l}\text { Streptomycin- } 10 \mathrm{mcg} / \mathrm{disc} \\
{[\mathbf{4 3}]}\end{array}$ & \multicolumn{4}{|c|}{$19+1.4$} & \multicolumn{4}{|c|}{$25.5+0.5$} \\
\hline
\end{tabular}

*Values are average of triplicate determinations and standard deviations were negligible

\subsubsection{Antiplasmodial activity study}

The relative activity as the $\mathrm{IC}_{50}$ [parental compound//C $\mathrm{I}_{50}$ (metal complex)] presented in Table 3 showed that FephenDox (3) was the most active among all the complexes, though only in the same range with doxycycline, the parent compound from which it was derived, while complex 1 showed no activity in the concentration range tested. The presence of iron in the complexes did not add to the antibacterial activity of the complexes but rather reduced it to a small extent. Complexation of iron alone reduced the antiplasmodial activity of complex 1 to a large extent, while it can be said that the presence of ancillary polypyridyl lig- ands compensated for this reduced antiplasmodial activity and that a more planar the polypyridyl ligand improves the antiplasmodial activity of the complex. Iron(III) chloride has been reported to reduce biological activity of tetracyclines [44].

This suggests that the antiplasmodial activity of the complexes could be associated with the interaction of the planar aromatic rings of the complexes with the parasitic DNA. Complex 3 which bears 1,10-phenathroline which is more planar than 2,2'-bipyridine in complex 2 exerted the higher activity between the complexes. However, the activities of all the complexes were lower than that of chloroquine diphosphate.

Table 3

Antiplasmodial activity of doxycycline and its complexes

\begin{tabular}{lcc}
\hline \hline Compound & IC $_{\mathbf{5 0}} / \boldsymbol{\mu g} / \mathbf{m l}$ * & Relative activity to Dox /IC $\mathbf{5 0}_{\mathbf{5 0}}$ \\
\hline $\mathbf{1}$ & $>100 \pm \mathrm{ND}$ & $\mathrm{ND}$ \\
$\mathbf{2}$ & $39 \pm 10.8$ & 0.26 \\
$\mathbf{3}$ & $11 \pm 5.5$ & 0.91 \\
Dox hyclate & $10 \pm 0.7$ & \\
Chloroquine diphosphate (CQDP) & $0.02 \pm 0.004$ & 500 \\
\hline \hline
\end{tabular}

*Values are average of triplicate determinations. $\mathrm{ND}=$ not determined

\subsection{DNA binding}

Monitoring the changes in absorption spectra of metal complexes upon the addition of increasing amounts of DNA is one of the most widely used methods for determining overall binding constants of metal complexes to DNA [38]. Upon the addition of calf thymus DNA to $\mathbf{2}$ and $\mathbf{3}$, there was a decrease in molar absorptivity (hypochrom- ism) of the absorption bands of the complexes indicating interaction of the complexes to DNA. To quantitatively compare the binding strength of these complexes, their intrinsic binding constants with CT-DNA were obtained by monitoring the changes in absorption bands (Fig. 3) with increasing concentration of DNA using equation 1 and were found to be $5.6 \times 10^{4}$ and $4.8 \times 10^{4}$ for complexes $\mathbf{2}$ and $\mathbf{3}$, respectively. 

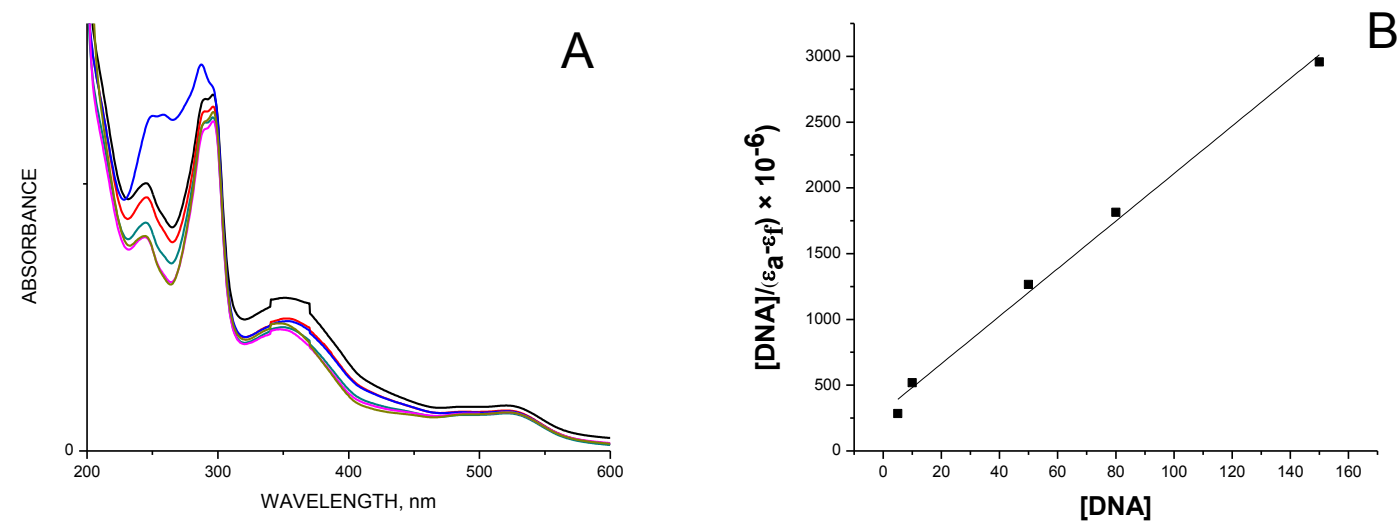

B
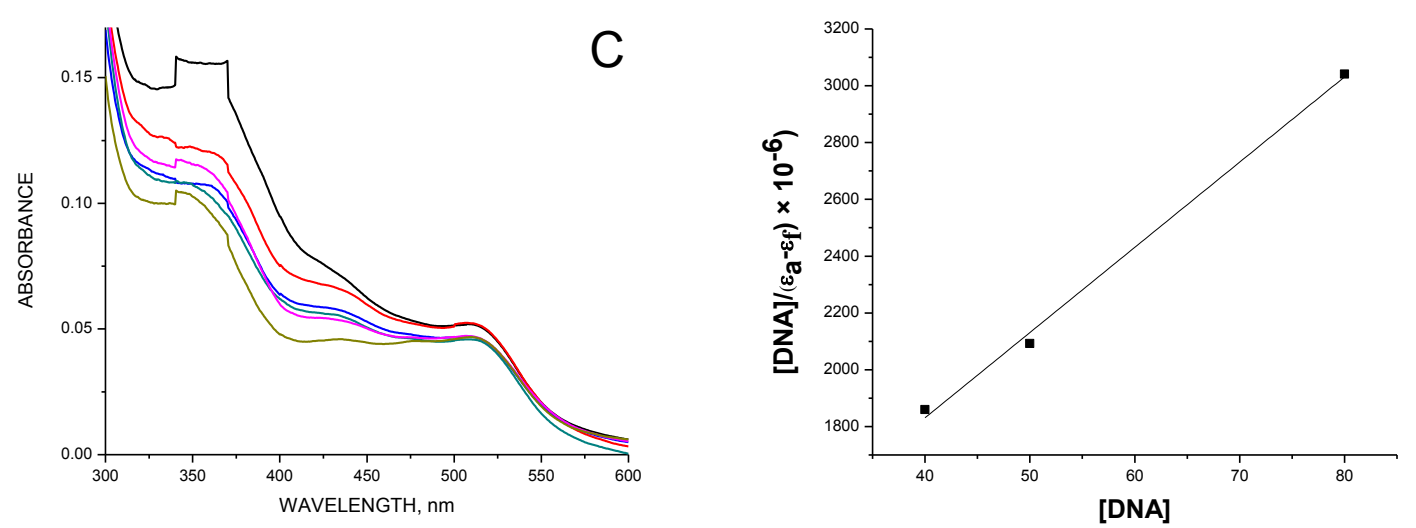

Fig. 3. Graphs showing the electronic absorption spectra of $20 \mu \mathrm{M}$ complexes $\mathbf{2}$ (A) and $\mathbf{3}$ (C) with increasing concentrations of CT-DNA in $50 \mathrm{mmol} \mathrm{NaCl}$ and $5 \mathrm{mmol}$ Tris $\mathrm{HCl}$ buffer at $\mathrm{pH}$ 7.2. B and D show a fitting of the absorbance data at $412 \mathrm{~nm}$ for complex 2 and $413 \mathrm{~nm}$ for complex 3 used to obtain the binding constants.

\section{CONCLUSION}

Three iron(III) complexes of the antibiotic doxycycline have been synthesized and well characterized by elemental analysis, UV-vis, FT-IR and electrospray mass spectroscopy. The three complexes showed some activity against strains of Staphylococcus aureus and Klebsiella pneumonia. The ancillary polypyridyl ligands did not contribute implicitly to the antimicrobial activities of these complexes. In addition, the coordination of iron in the complexes reduced their antibacterial activity, while the ancillary polypyridyl ligands compensated for the reduced antiplasmodial activity. The more planar the polypyridyl ligand, the higher the antiplasmodial activity of the complex. The complexes were also found to interact with DNA with binding constants $5.6 \times 10^{4}$ and $4.8 \times 10^{4}$ for complexes $\mathbf{2}$ and $\mathbf{3}$, respectively.

Acknowledgments. The authors appreciate STEP-B project and University of Ilorin for financial support; OOA appreciates The World Academy of Science (TWAS) and DBT, India for Postgraduate Fellowship (FR number: 3240240274) to Savitribai Phule Pune University, Pune, India.

\section{REFERENCES}

[1] S. K. Roy, D. Kendrick, B. D. Sadowitz, L. Gato, K. Snyder, J. M. Satalin, L. M. Golub, G. Nieman, Jack of all trades: pleiotropy and the application of Chemically Modified Tetracycline-3 in Sepsis and the Acute Respiratory Disease Syndrome (ARDS), Pharmacol Res., 64(6), 580589 (2011). DOI: 10.1016/j.phrs.2011.06.012

[2] M. O. Griffin, G. Ceballos, F. Villarreal, Tetracycline compounds with non-antimicrobial organ protective properties: possible mechanisms of action, Pharmacol Res., 63(2), 102-107 (2011). DOI: 10.1016/j.phrs.2010.10.004

[3] M. O. Griffin, E. Fricovsky, G. Ceballos, F. Villareal, Tetracyclines: a pleiotropic family of compounds with promising therapeutic properties: Review of literature, Am J Cell Physiol, 299(3), C539-C548 (2010). DOI: 10.1152/ajpcell.00047.2010

[4] K. R. Tan, A. J. Magill, M. E. Parise, P. M. Arguin, Doxycycline for malaria chemoprophylaxis and treatment: report from the CDC expert meeting on malaria chemoprophylaxis, Am. J Trop Med Hyg., 84(4), 517534 (2011). DOI: 10.4269/ajtmh.2011.10-0285

[5] T. Gaillard, M. Madamet, B. Pradines, Tetracyclines in malaria, Malar J., 14(1), 445 (2015). DOI: 10.1186/s12936-015-0980-0 
[6] J. T. Peterson, Matrix metalloproteinase inhibitor development and the remodelling of drug discovery, Heart Fail Rev., 9(1), 63-79 (2014).

DOI:10.1023/B:HREV.0000011395.11179.af

[7] W. Wu, L-h. Yu, B. Ma, M-j. Xu, The inhibitory effect of doxycycline on cisplatin-sensitive and -resistant epithelial ovarian cancer, PLOS ONE, 9(3) e89841 (2014). DOI: 10.1371/journal.pone.0089841

[8] H. Tang, P. Sampath, X. Yan, S. H. Thorne, Potential for enhanced therapeutic activity of biological cancer therapies with doxycycline combination, Gene Ther., 20(7), 770-778 (2013). DOI: 10.1038/gt.2012.96

[9] K. Son, S. Fujioka, T. Iida, K. Furukawa, T. Fujita, H. Yamada, P. J. Chiao, K. Yanaga, Doxycycline induces apoptosis in PANC-1 pancreatic cancer cells, Anticancer Res., 29(10), 3995-4003 (2009).

[10] Z. Saikali, G. Singh, Doxycycline and other tetracyclines in the treatment of bone metastasis, Anticancer Drugs, 14(10), 773-778 (2003). DOI:10.1097/01.cad.0000099002.92896.cf

[11] M. E. Ryan, A. Usman, N. S. Ramamurthy, L. M. Golub, R. A. Greenwald, Excessive matrix metalloproteinase activity in diabetes: Inhibition by tetracycline analogues with zinc reactivity, Curr Med Chem., 8(3), 305-316 (2001). DOI: 10.2174/0929867013373598

[12] L. M. Golub, N. S. Ramamurthy, T. F. McNamara, R. A. Greenwald, B. R. Rifkin, Tetracyclines inhibit connective tissue breakdown: New therapeutic implications for an old family of drugs, Crit Rev Oral Biol Med., 2, 297321 (1991).

DOI: https://doi.org/10.1177/10454411910020030201

[13] L. M. Golub, H. M. Lee, M. E. Ryan, W. V. Giannobile, J. Payne and T. Sorsa, Tetracyclines inhibit connective tissue breakdown by multiple non-antimicrobial mechanisms, Adv Dent Res., 12, 12-26 (1998). DOI: https://doi.org/10.1177/08959374980120010501

[14] M. A. Khan, J. Mustafa, Mechanism of DNA strand breakage induced by photosensitized tetracycline- $\mathrm{Cu}(\mathrm{II})$ complex, Mutation Research, 525, 109-119 (2003). DOI: 10.1016/S0027-5107(03)00008-3

[15] P. P. Silva, W. Guerra, J. N. Silveira, A. M. C. Ferreira, T. Bortolotto, F. L. Fischer, H. Terenzi, A. Neves, E. C. Pereira-Maia, Two new ternary complexes of copper(II) with tetracycline or doxycycline and 1,10phenanthroline and their potential as antitumoral: cytotoxicity and DNA cleavage, Inorg. Chem., 50 (14), 6414-6424 (2011). DOI: 10.1021/ic101791r

[16] T. Bortolotto, P. P. Silva, A. Neves, E. C. Pereira-Maia, H. Terenzi, Photoinduced DNA cleavage promoted by two copper(II) complexes of tetracyclines and 1,10phenanthroline, Inorg. Chem., 50 (21), 10519-10521 (2011). DOI: $10.1021 /$ ic201349s

[17] W. W. Brandt, F. P. Dwyer, E. C. Gyarfas, Chelate complexes of 1,10-phenanthroline and related compounds, Chemical Reviews, 54, 959-1017 (1954). DOI: $10.1021 / \mathrm{cr} 60172 \mathrm{a} 003$

[18] M. McCann, M. Geraghty, M. Devereux, D. O’Shea, J. Mason, L. O'Sullivan, Insights into the mode of action of the anti-Candida activity of 1,10-phenanthroline and its metal chelates, Metal Based Drugs, 7(4), 185-193 (2000). DOI: 10.1155/MBD.2000.185
[19] L. Salassa, Polypyridyl Metal Complexes with biological activity, Eur. J. Inorg. Chem., 32, 4931-4947 (2011). DOI: https://doi.org/10.1002/ejic.201100376

[20] E. C. Constable, Homoleptic complexes of 2,2'bipyridine, Adv. Inorg. Chem., 34, 1-63 (1989). DOI: https://doi.org/10.1016/S0898-8838(08)60014-8

[21] G. Chelucci, R. P. Thummel, Chiral 2,2‘-bipyridines, 1,10-phenanthrolines, and $2,2^{`}: 6^{`}, 2^{\prime}$ '-terpyridines: Syntheses and applications in asymmetric homogeneous catalysis, Chem. Rev., 102(9), 3129-3170 (2002). DOI: $10.1021 / \mathrm{cr} 0101914$

[22] N. Mudasir, H. I. Yoshioka, Iron(II) and nickel(II) mixed-ligand complexes containing 1,10-phenanthroline and 4,7-diphenyl-1,10-phenanthroline, Transition Met. Chem., 24(2), 210-217 (1999).

DOI: $10.1016 / \mathrm{S} 0162-0134(99) 00206-8$

[23] M. Riaz, N. J. Pilpel, Complexation of tetracyclines with metal ions in relation to photosensitization, Pharm. Pharmacol., 36, 153-156 (1984).

DOI: https://doi.org/10.1111/j.2042-7158.1984.tb06929.x

[24] D. Grenier, M-P. Huot, D. Mayr, Iron-chelating activity of tetracyclines and its impact on the susceptibility of Actinobacillus actinomycetemcomitans to these antibiotics, Antimicrob. Agents Chemother., 44, 763-766 (2000).

[25] S. Saha, D. Mallick, R. Majumdar, M. Roy, R. R. Dighe, E. D. Jemmis, A. R. Chakravarty, Structure-activity relationship of photocytotoxic iron(III) complexes of modified dipyridophenazine ligands, Inorg. Chem., 50(7), 2975-2985 (2011). DOI: 10.1021/ic1024229

[26] A. Terenzi, G. Barone, A. Silvestri, A. M. Giuliani, A. Ruggirello, V. T. Liveri, The interaction of native calf thymus DNA with $\mathrm{Fe}^{\mathrm{III}}$-dipyrido[3,2-a: 2',3'-c]phenazine, J. Inorg. Biochem, 103, 1-9 (2009). DOI: $10.1016 /$ j.jinorgbio.2008.08.011

[27] G. M. Keating, Ferric carboxymaltose: a review of its use in iron-deficiency, Drugs, 75(1), 101-127 (2015). DOI: $10.1007 / \mathrm{s} 40265-014-0332-3$

[28] I. C. Macdougall, Evolution of IV iron compounds over the last century, J Ren Care., 35(2), 8-13 (2009). DOI: $10.1111 / \mathrm{j} .1755-6686.2009 .00127 . \mathrm{x}$

[29] P. Ponikowski, D. J. van Veldhuisen, J. Comin-Colet, G. Ertl, M. Komajda, V. Mareev, T. McDonagh, A. Parkhomenko, L. Tavazzi, V. Levesque, C. Mori, B. Roubert, G. Filippatos, F. Ruschitzka, S. D. Anker, Beneficial effects of long-term intravenous iron therapy with ferric carboxymaltose in patients with symptomatic heart failure and iron deficiency, European Heart Journal, 36(11), 657-668 (2014). DOI: 10.1093/eurheartj/ehu385

[30] J A. Obaleye, A. C. Tella, W. A. Osunniran, N. Simon, P. F. Omojasola, Synthesis, characterization, crystal structure and antimicrobial evaluation of a novel $-\mathrm{M}-\mathrm{X}-$ $\mathrm{M}-\mathrm{X}$ - type infinite chain 1D $\mathrm{Cu}(\mathrm{II})$ complex with eflornithine hydrochloride hydrate as ligand, J. Inorg and Organomet Polymer Mater, 24(5), 827-835 (2014). DOI: https://doi.org/10.1007/s10904-014-0052-X

[31] O. O. Abosede, N. A. Vyas, S. B. Singh, A. Kumbhar, A. N. Kate, A. A. Kumbhar, A. Khan, A. Erxleben, P. Smith, C. de Kock, F. Hoffmann, J. Obaleye, Copper(II) mixed ligand polypyridyl complexes with doxycycline - 
structures and biological evaluation, Dalton Trans., 45, 3003-3012 (2016).

DOI: $10.1039 / \mathrm{c} 5 \mathrm{dt} 04405 \mathrm{~g}$

[32] A. C. Tella, J. A. Obaleye, U. B. Eke, A.Y. Isaac, O. M. Ameen, Solvent-free synthesis, X-ray studies and in vitro inhibitory activities of copper(II) complexes of non-steroidal anti-inflammatory drugs, Res. Chem. Interm. 40, 1441-1457 (2014).

DOI: https://doi.org/10.1007/s11164-013-1050-2

[33] J. A. Obaleye, O. O. Abosede, A. S. Kumbhar, O. A. Majolagbe, Syntheses, characterization and antibacterial susceptibility testing of transition metal complexes of doxycycline, Can Chem Trans., 4(2), 168-179 (2016). DOI:10.13179/canchemtrans.2016.04.02.0257

[34] M. Cheesbrough, District Laboratory Practice in Tropical Countries, Part 2, Cambridge University Press, Cambridge, UK, 2006, p. 137-150.

[35] W. Trager, J. B. Jensen, Human malaria parasite in continuous culture, Science, 193, 673-675 (1976). DOI: $10.1126 /$ science. 781840

[36] M. T. Makler, J. M. Ries, J. A. Williams, J. E. Bancroft, R. C. Piper, B. L. Gibbins and D. J. Hinrichs, Parasite lactate dehydrogenase as an assay for Plasmodium falciparum drug sensitivity, Am. J. Trop. Med. Hyg., 48, 739-741 (1993). DOI: https://doi.org/10.4269/ajtmh.1993.48.739

[37] V. A. Kawade, A. A. Kumbhar, A. S. Kumbhar, C. Nather, A. Erxleben, U. B. Sonawane, R. R. Joshi, Mixed ligand cobalt(II) picolinate complexes: synthesis, characterization, DNA binding and photocleavage, Dalton Trans., 40, 639-650 (2011). DOI: 10.1039/c0dt01078b

[38] S. S. Bhat, A. A. Kumbhar, H. Heptullah, A. A. Khan, V. V. Gobre, S. P. Gejji, V. G. Puranik, Synthesis, elec- tronic structure, DNA and protein binding, DNA cleavage, and anticancer activity of fluorophore-labeled copper(II) complexes, Inorg. Chem., 50, 545-558 (2011). DOI: $10.1021 /$ ic $101534 \mathrm{n}$

[39] C. V. Kuman. E. H. Asuncion, DNA-binding studies and site-selective fluorescence sensitization of an anthryl probe, J. Am. Chem. Soc., 115, 8547-8553 (1993). DOI: $10.1021 / \mathrm{ja} 00072 \mathrm{a} 004$

[40] A. Wolfe, G. H. Shimer, T. Meehan, Polycyclic aromatic hydrocarbons physically intercalate into duplex regions of denatured DNA, Biochemistry, 26, 63926396 (1987). DOI: 10.1021/bi00394a013

[41] T.G. Emori, R. P. Gaynes, An overview of nosocomial infections, including the role of the microbiology laboratory, Clin. Microbiol. Rev., 6, 428-442 (1993).

DOI: 10.1128/CMR.6.4.428

[42] K. Shameli, M. B. Ahmad, M. Zargar, W. M. Z. W. Yunus, A. Rustaiyan, N. A. Ibrahim, Synthesis of silver nanoparticles in montmorillonite and their antibacterial behavior, International Journal of Nanomedicine, 6, 581-590 (2011). DOI: 10.2147/IJN.S17112

[43] S. M. Sivakumar, M. M. Safhi, Isolation and screening of bioactive principle from Chaetomorpha antennina against certain bacterial strains, Saudi Pharmaceutical Journal, 21, 119-121 (2013). DOI: $10.1016 /$ j.jsps.2012.02.003

[44] B. Pradines, C. Rogier, T. Fusai, J. Mosnier, W. Daries, E. Barret, D. Parzy, In vitro activities of antibiotics against Plasmodium falciparum are inhibited by iron, Antimicrob. Agents Chemother., 45, 17460-1750 (2001). DOI: 10.1128/AAC.45.6.1746-1750.2001 